\title{
Human Resource Development Practices: Empirical Evidence from Nepal Rastra Bank
}

\author{
Achyut Gnawali * \\ Central Department of Management, Tribhuvan University, Kirtipur, Kathmandu,Nepal \\ Corresponding Email: * tu_mgmt@hotmail.com
}

\begin{abstract}
Human resource development (HRD) is the process of increasing knowledge, skills and capacities of employees. It is concerned with preparing employee to work effectively and efficiently in the organization. It is a complementary approach to other development strategies, particularly employment and reduction of inequalities. It also considers HRD as synonymous with human development, which encompasses education, training, health, nutrition, and fertility reduction. It ensures that organizations have adequate human resources with capabilities needed for achieving goals. This article has tried to explore the practices and relation between HRD and performance of Nepal Rastra Bank.
\end{abstract}

Keywords: Human resource development, performance, organization, Nepal Rastra Bank

\section{INTRODUCTION}

$\mathrm{H}$ UMAN resource is regarded as the most significant and precious resource in every organizations. Dynamic, motivated and energetic resources can form a successful organization. Employees can contribute and play vital role, contributing their expertise, time and energy to make organization effective, profitable, and to be success in overall aspect of the business.

Heartly and Morley (1997) believe that the ability to recognize and prioritize trainings and development activities or programmes as per needs of organization to maximize benefit remain underpinning function for developing training and development of human resource. Employees' training and development is considered as an important part of human resource development. Training is an ongoing planned short term process utilizing organized measures from which employees acquire knowledge and skills, in term of definite work to be done. Training helps to people modifying their attitude, knowledge and skills throughout the learning experience to achieve better performance. Similarly, the term development refers to a broader and a long term instructive processes in which managers or employees obtain theoretical knowledge. Learning is practical and employees learn through their work process and learning environment.

Organizational or employees' performance exclusively depends how the organization develops and educates its employees. "Distinctive human resource development practice shape the core competencies that determine how firm competes" (Armstrong, 2015, p10).Similarly CIMA(2013) suggests that "Human resource development may be seen as a process of building and enhancing the skills, knowledge and attitude of employees". Human resource development in any organization is therefore concerned with developing competencies of employees in organizational setting. HRD helps to organization to improve capabilities, enhance effectiveness, faster team work, increase job satisfaction, improve decision-making; manage change, conflict and environmental adoption. Human resource development is the development of the employees for the better competencies, dynamism, motivation, and effectiveness (Rao, 1998). HRD aims on persistently appraising the proficiency necessities of persons to perform the job and responsibility given to them. It also aims at preparing people for performing their roles or functions which they may require to perform in the future as they go up in the organizational hierarchy or as the organization takes up new tasks through diversification, expansion, modernization, economization, etc. HRD tries to develop the potentiality on employees for future jobs roles in the organization' (Rao, 1998).

Redman and Wilkinson (2006), suggested that human resource development is concerned with developing human competencies throughout time-bound and planned learning practice to improve the creative input of people to achieve organizational goals. Managers of organizations, get the jobs done by working with and through mobilizing people in right time and in right places. Human resources need to be developed continuously as a result, organizations perform to achieve their goals efficiently and effectively.

"Globalization and needs for the companies to gain sustainable competitive advantage require new and different approaches to recruitment, training, developing and retaining the employees with key skills" (Wilson, 2005, p.156). Human resource development has the greater role in each and every types of organization regardless whether it is profitable or non profitable. There are various functions of HRD like training, management development, career development and planning, performance appraisal, employees counseling and welfare.

To sum up, from the above literature review several international researches have been carried out on human resource development, employees' trainings and organizational performance. In Nepalese context, it is perhaps a new, least priority sectors and ignored area of inquiry. Only a few previous researches conducted in the topic of human resource management and need of training, trend of training and development programmes. Therefore, present research may be a valuable piece of work for academician, practitioners as well as the bank management to understand of importance of human resources development in relation to organizational performance and more importantly to take corrective actions.

"Human resource development is a process of developing and unleashing expertise for the purpose of improving 
individual, team, work process, and organizational system performance" (Swanson and Elwood, 2009, p.4). In the organizational context, the development of any individual means the acquisition of innovative capabilities. It makes them able to perform their duties easily and effectively. As human resources development assumes the concept of treating human beings as a great asset of the organization, it certainly contributes on the achievement of organizational goals (Wilson, 2005).

Human resource development is both means and ends. It is a conscious and continuous process of increasing the knowledge, education and skill of the people at any possible age so that organizational performance can be improved. Such efforts enable the people to develop fully their physical, mental, social, cultural aesthetic potentialities. 'Learning and performance is associated these factors can be seen as a formula for success' (Swanson and Elwood, 2009, p. 4).

\section{RESEARCH QUESTIONS}

Human resource development is very important aspect for an organization. One of the main issues and trend of HRD includes the training and development. For the growth of an organization and achieve its objectives, training and development is considered as an inevitable facet because it aims to develop employees skills, knowledge, attitude, capabilities, and efficiencies. In order to achieve desired goals; employees training and development plays most vital role in each and every type of organizations.

Therefore, this study is mainly aimed at examining whether or not Nepal Rastra Bank adopted effective employees' training programmes. Whether or not these programmes enhance organizational performance? What type of working climate is there, how employees react or feel being part or members in the organization? As for competitive advantages and overall success of an organization, these are the determinant factors. Systematically, it can be presented as:-

a. To what extent Nepal Rastra Bank has adopted the training and development program?

b. What is the link between employee development and performance?

\section{OBJECTIVES OF THE STUDY}

The primary objective of this research is to investigate and see the employees' development and organizational performance. In addition this research intends to examine the training and development practices adopted by Nepal Rastra Bank. More specifically, this study is directed towards the following objectives.

a. To review the training, development policy and practices, adopted by the NRB.

b. To establish the link between employees development and organizational performance.

\section{RESEARCH MEthodology}

This study follows descriptive as well as analytical research design to analyze the data. It is primarily exploratory and analytical in nature as it explores how far the human resource and employee development programs help enhance the organizational performance as well as help the management and employees in fulfilling their job responsibilities. Design of the present study is based on survey. Primary data shall extensively be used in this research. A carefully designed questionnaire method is used to collect the primary data. The researcher has cautiously designed the questionnaire taking into consideration various factors of employee development and performance, sources of human resource development and result of the previous research related on similar areas or topic. Basic sources of primary information have been the employees of Nepal Rastra Bank central office and banking office Kathmandu, Nepal.

Primary data widely is used in this research. However, the author has reviewed the existing literature for in-depth analysis. First, the author has reviewed available literature of human resource management and employee training and development and performance. For the literature review, the research is relied on secondary data to gather information from different previous researched articles, books, magazines, news papers, journals, internet and media wherever applicable. A large number of employees have been working in NRB, therefore, the present study has not covered all the employees of the bank because of time and resource constraint. However, the research attempts to cover as many employees as possible to make the result accurate. The researcher had administered 180 questionnaires to collect the information or data. From the respondents 155 questionnaires were collected and 149 useable questionnaires were deployed in data analysis.

Questionnaires were administered and returned in ten days. To meet the stated objectives used for design, a standard format sheet was used for tabulation and data analysis. Simple descriptive statistical tools such as table, excel, and bar diagram are used for data presentation and analysis.

\section{PResentation AND Analysis of Data}

The current chapter shows the presentation and analysis of relevant data related to this research, in tabular, pie chart and bar-diagram forms. It also analyses and interprets the data in such a way that the stated objectives can be fulfilled. This chapter mainly highlights data interpretation and the result of the study. One hundred and eighty questionnaire sheets were administered to collect the data and 155 questionnaires were collected from the respondents. However, only one hundred forty nine (149) responses were used in the analysis. Researcher could not incorporate all employees in the research; nevertheless, to make the study more realistic and accurate, information was gathered from different department such as currency and forex, bank finance supervision management, research department, human resource department, information technology, 
corporate planning, public debt, general service and banking office by sampling method.

Respondents were asked 20 questions in total. And, 9 questions were related to training and development policy and practice, and 11 questions associated to link between employee development and organizational performance of Nepal Rastra Bank. The researcher developed the questionnaires in the form of yes-no, agree-disagree and give opinion to take the view of participants. A general overview of all items and other aspects such as training and development of employees, organizational climate and performance evaluation and employee development planning can be a valuable aid to make a conclusion.

\subsection{To what extent Nepal Rastra Bank has adopted the} training and development program?

Human resource development function begins with training and development practices and any other skill development program of human resources. For the research purpose, nine questionnaires were designed and administered to collect information to assess the training effectiveness policies and practices of NRB. Respondents were asked to answer the questions to assess the employees training and development policies and practices adopted by Nepal Rastra Bank.

TABLE 1

Descriptive analysis of training and development practice:

\begin{tabular}{|c|c|c|c|c|}
\hline $\begin{array}{l}\text { S. } \\
\text { No. }\end{array}$ & $\begin{array}{c}\text { Statements asked to } \\
\text { Respondents }\end{array}$ & $\begin{array}{l}\text { Agreed } \\
\text { (No.) }\end{array}$ & $(\%)$ & $\begin{array}{l}\text { Disagreed } \\
\text { (No.) }\end{array}$ \\
\hline 1 & $\begin{array}{l}\text { Are employees training } \\
\text { given adequate } \\
\text { importance in NRB? }\end{array}$ & 104 & 69.8 & 45 \\
\hline 2 & $\begin{array}{l}\text { Training provided here } \\
\text { are well-planned. (Do } \\
\text { you agree or disagree?) }\end{array}$ & 71 & 47.65 & 78 \\
\hline 3 & $\begin{array}{l}\text { Is training and } \\
\text { development programmes } \\
\text { of sufficient duration? }\end{array}$ & 48 & 32.2 & 101 \\
\hline 4 & $\begin{array}{l}\text { Training provided here } \\
\text { gives good opportunity to } \\
\text { new comers to learn } \\
\text { about this organization. }\end{array}$ & 119 & 80.0 & 40 \\
\hline 5 & $\begin{array}{l}\text { Norms and values of the } \\
\text { organization are clearly } \\
\text { explained to new } \\
\text { employees during the } \\
\text { training? }\end{array}$ & 103 & 69.0 & 46 \\
\hline 6 & $\begin{array}{l}\text { Are senior executives } \\
\text { take much interest and } \\
\text { spend significant time } \\
\text { with new staff during the } \\
\text { training. }\end{array}$ & 48 & 32.2 & 101 \\
\hline 7 & $\begin{array}{l}\text { Is the training } \\
\text { periodically evaluated } \\
\text { and improved here? }\end{array}$ & 69 & 46.3 & 80 \\
\hline 8 & $\begin{array}{l}\text { Do Employees acquire } \\
\text { technical knowledge and } \\
\text { skill through training? }\end{array}$ & 63 & 42.3 & 86 \\
\hline 9 & $\begin{array}{l}\text { Do employees in this } \\
\text { organization participate } \\
\text { in training assessment? }\end{array}$ & 70 & 47.0 & 79 \\
\hline
\end{tabular}

The above table 1 presents the number and $\%$ of respondents' and their views regarding the employees' training and development practice adopted by Nepal Rastra Bank.

The data presented in the table above clearly shows that the majority of the respondent (around $70 \%$ ) supported the fact that NRB gives adequate importance to the employees training. Only $30 \%$ of the respondents were against this issue. They said that NRB didn't give importance to developing training and development program for the employees.

Regarding the planning of the training, majority of the respondents $(52 \%)$ agreed that the training provide in NRB was not well-planned whereas only $48 \%$ of the respondent were positive regarding the training of the NRB which they regarded as well-planned.

Most of the respondents surveyed (68\%) reveled their disagreement regarding the statement- 'training and development program are of sufficient duration'. Only $32 \%$ of the respondents were in favor of this statement. It clearly points out the shortcomings in the training and development program provided by the NRB.

Regarding the provision of learning opportunity provided to new comers, most of the respondents $(80 \%)$ agreed that NRB provides learning opportunity to new comers whereas $20 \%$ of the respondents were against this view. Though, It is a positive sign. Employees feel motivated and empowered when they are provided with opportunity to learn and excel.

$\mathrm{NRB}$ has been found to have the culture of explaining the norms and values to the new comers during training which is supported by the $69 \%$ of the respondent. Only $30 \%$ of the respondents disagreed on it. This indicated that new employees get significant time and an opportunity of learning about the organization.

Majority of the respondents (68\%) opposed the statement that that the senior executives participate and spend significant time during the training with the junior staff. Only $32 \%$ of the employees surveyed supported this statement. This indicates that the senior executives and managers seem to be not much serious towards their junior employees development and learning.

Regarding the query about the periodic evaluation and improvement of training in NRB, $54 \%$ of the respondents showed disagreement and only $46 \%$ agreed that NRB periodically evaluates and improves the training program. This indicates that training need assessment system in NRB is of weak states. Also, it indicates the training evaluation is not adequately practiced here.

Forty three percent age of respondents reported that they acquired technical knowledge and skills through the trainings, learning and development programs, whereas 54\% of the respondents were found against the opinion. This result is a clear indication that employees do not acquire sufficient technical knowledge.

Regarding training need assessment, majority (53\%) reported that they don't take part in training need assessment 
prior to designed and carry out the trainings whereas only 47 $\%$ of them reported that they are provided this opportunity. So, it means that NRB lacks the practice of involving employees in decision making and assessment process in relation to training development and implementation.

In summary, it is found that there was disagreement among employees in the majority of areas of human resource development program 6 areas. Employees agreed on only three areas of human resource development programs. Therefore, it demonstrates that employee development policies and practices in Nepal Rastra Bank is found to be in unsatisfactory level. Employees of Nepal Rastra Bank perceived that the bank is not adequately able to adopt employee or human resource development practices.

5.2 What is the link between employee training, development and performance?

To investigate the link between employees' development and organisational performance, the questionnaires consisting of 11 topics questions were delivered to collect the information from the respondents. Altogether 149 participants were involved in this survey. Most of the respondents emphasized on competent manpower and training, development, education, foreign visit, required nutrition (Employees Development) help to enhance the performance. Well skilled, creative, good knowledge and active employees boost up effective communication, implementation of plans and policies, good coordination, motivation and proper monitoring and evaluation with due rewards and punishment.

The table 2 presents the agreement and disagreement of the respondents and their respective percentage in regards to link between employee development and performance.

In response to the statement: Human Resource development helps in corporate governance, coordination and motivation, $69 \%$ of the respondents agreed and only $31 \%$ expressed their disagreement. This indicates that if organization takes an initiative in an effective human resource management, it would help in enhance good governance, capacity, motivation and coordination of organization.

Regarding the query of Training and Development, majority of the respondents (68\%) expressed their agreement on the statement: Training and development of the employees helps for change management, whereas $32 \%$ of the respondents were against it. It is obvious that the majority of the respondents in regard to training and development as an important tool for change management. To find out the view of employees regarding employee development, they were asked to cast their views on the statement: Employees' development helps to enhance the sense of confidence to which majority of the respondents (62\%) agreed and $38 \%$ expressed their disagreement. It indicated that most of the employees in NRB perceive that employee training and development programmes create a sense of confidence in them. Majority of the respondents $(60 \%)$ agreed on the opinion that 'training helps the organization to change the challenges into opportunities and weaknesses into strengths.' While rest for the against this statement. It indicates that to strengthen the organizational capacity, employees should be trained and developed.

TABLE 2

Analysis link between Employee training, Development \& Performance:

\begin{tabular}{|c|c|c|c|c|c|c|}
\hline $\begin{array}{c}\text { S. } \\
\text { No. }\end{array}$ & Statements & $\begin{array}{c}\text { Agree } \\
\text { d } \\
\text { (No.) }\end{array}$ & $\%$ & $\begin{array}{l}\text { Disa } \\
\text { gree } \\
\text { d } \\
\text { (No.) } \\
\end{array}$ & $\%$ & $\begin{array}{c}\text { Total } \\
\text { Respo } \\
\text { ndent } \\
\text { s } \\
\end{array}$ \\
\hline 1 & $\begin{array}{l}\text { Human Resource } \\
\text { development helps in } \\
\text { corporate } \\
\text { governance, } \\
\text { coordination and } \\
\text { motivation. }\end{array}$ & 103 & 69.0 & 46 & 31.0 & \\
\hline 2 & $\begin{array}{l}\text { Training and } \\
\text { development of } \\
\text { employees helps for } \\
\text { change management. }\end{array}$ & 101 & 67.8 & 48 & 32.2 & \\
\hline 3 & $\begin{array}{l}\text { Employees' } \\
\text { developments help } \\
\text { enhance the sense of } \\
\text { confidence. }\end{array}$ & 93 & 62.4 & 56 & 37.6 & \\
\hline 4 & $\begin{array}{l}\text { "Training helps the } \\
\text { organization to } \\
\text { change the challenges } \\
\text { into opportunities and } \\
\text { weaknesses into } \\
\text { strengths" }\end{array}$ & 89 & 59.7 & 60 & 40.3 & \\
\hline 5 & $\begin{array}{l}\text { Training, } \\
\text { development helps to } \\
\text { improve productivity, } \\
\text { market share, } \\
\text { reputation, image, } \\
\text { prestige and efficient } \\
\text { use of resources. }\end{array}$ & 92 & 61.7 & 57 & 38.3 & \\
\hline 6 & $\begin{array}{l}\text { Employee } \\
\text { development helps in } \\
\text { corporate } \\
\text { governance, }\end{array}$ & 78 & 54.4 & 68 & 45.6 & (149) \\
\hline 7 & $\begin{array}{l}\text { Trainings and } \\
\text { development for } \\
\text { employees help for } \\
\text { change management } \\
\text { and grievance } \\
\text { handling effectively } \\
\text { and efficiently. }\end{array}$ & 65 & 43.6 & 84 & 56.4 & \\
\hline 8 & $\begin{array}{l}\text { "Training helps to } \\
\text { change challenges } \\
\text { into opportunities and } \\
\text { weaknesses into } \\
\text { strengths in the } \\
\text { changing } \\
\text { environments" }\end{array}$ & 109 & 73.0 & 40 & 27 & \\
\hline 9 & $\begin{array}{l}\text { Employees' } \\
\text { development helps to } \\
\text { improve productivity, } \\
\text { market share, } \\
\text { reputation, image, } \\
\text { prestige and } \\
\text { efficiency. }\end{array}$ & 79 & 53.0 & 70 & 47.0 & \\
\hline 10 & $\begin{array}{l}\text { Employees } \\
\text { developments help } \\
\text { enhance motivation } \\
\text { of personnel. }\end{array}$ & 103 & 69.0 & 46 & 31.0 & \\
\hline
\end{tabular}

Source: Field Survey, 2015

Regarding the benefits of training and development program majority of the respondents (62\%) agreed on the statement: training and development helps to improve productivity, 
market share, reputation, image, prestige and efficient use of resources. On the contrary, only $38 \%$ of the respondents showed their disagreement. This clearly shows that if the organization provides training and development programmes to its employees, it helps to improve productivity, extend market share, reputation in the market or customer. In addition, it also enhances the prestige of the organization as well as helps the efficient use of the resources.

Most of the respondents (54\%) opined that employees' development helps to promote corporate governance, coordination and motivation while $46 \%$ of the respondents were against this opinion. On the contrary, $56 \%$ of the respondents were found against the statement: training and development helps the change management and grievance management system and only $43 \%$ agreed to it. On the statement: training helps the organization to transform the changes into opportunity and weakness into strength, majority of the respondents (73\%) agreed and only $27 \%$ were against this opinion.

Employee's development program provides an opportunity for quick promotion and self development for the employees. Training and development programs enhance the capacity of the employees on their planning, organizing, directing and controlling task. This is supported by the respondents surveyed who opined that employees' development program helps to handle employee grievance and promotes productivity, confidence, discipline and selfesteem adherence. Majority of the respondents agreed that employee's training and development create a sense of confidence in the mind of employees in Nepal Rastra Bank.

Majority of the respondents (69\%) opined that there is a strong link between training and development programs and employees' commitment and dedication whereas only $31 \%$ of the respondents were against this opinion. Employees surveyed were also found positive regarding the role of the employee development program in promoting accountability and reducing mismanagement. Efficient employees' in NRB can implement plans, policy and strategy. Most of the respondents were agreed about this view.

Regarding the question in connection to the job satisfaction, it is found that training and development adds value of job satisfaction by changing employee attitudes and behavior towards jobs. It also heightened employee morale; reduced absenteeism and employees' turnover. Majority of the respondents (52\%) found that employees' development helps research and development activities, employees' creativity, internal control system, monitoring and supervision. Human resource development has improved decision making capabilities and cultured thinking of management. Well skilled employees have adjusted with job related problems. Trained employees helped subordinate to improve their performance that leads to employee participation and cooperation. The respondents agreed that employees' development equips the manager as well to proact as well as to respond to changing environmental forces. For the purpose of effective operation of financial and accounting system, each and every organization should follow the budgeting and financial management systems. Similarly, skilled man power have mobilized effectively and efficiently the budgeting and financial management system in NRB. Sometimes it was also found that there is a problem of goal congruence among the employees due to the lack of controlling. Regarding the question of quality of work life and commitment, they agreed that employees' development leads to commitment, readiness to change, societal wellbeing, cost effectiveness and implementation of monetary policies. From the interpretation of the data, it can be concluded that employees' training and development plays the significant role for overall development of any types of organizations. In Nepal Rastra Bank employees' development plays the crucial roles for the better performance. It is also found that there is a positive relationship between employees' development and performance of the organization. However, the study shows that training and development programmes and activities were insufficient in NRB. The data presented clearly indicates that EMPLOYEES training and development enhances the ORGANIZATIONAL performance.

\section{FINDINGS:}

The following findings have been derived from the current study.

- Majority of the respondents (around $70 \%$ ) supported the fact that NRB gives adequate importance to the employees training. Only $30 \%$ of the respondents were against this fact. They said that NRB didn't give importance to developing training and development program for the employees.

- Regarding the planning of the training, majority of the respondents $(52 \%)$ agreed that the training provided at NRB was not well-planned, whereas only $48 \%$ were positive of the training of the NRB .

- Most of the respondents surveyed (68\%) reveled their disagreement regarding the statement- 'training and development program are of sufficient duration'. Only $32 \%$ of the respondents were in favor of this statement. It clearly points out the shortcomings in the training and development program provided by the NRB.

- Regarding the provision of learning opportunity provided to the new comers, most of the respondents $(80 \%)$ agreed that NRB provides learning opportunity to new comers whereas $20 \%$ were against this view. But it is a positive sign. Employees feel motivated and empowered when they are provided with opportunity to learn and excel.

- Majority of the respondents (68\%) opposed the statement that the senior executives take part and spend significant time during the training with the junior. Only $32 \%$ surveyed supported this statement. This indicates that the senior executives and managers seem to be not very serious towards junior employees' development and learning.

- $\quad$ Forty three percentage age of the respondents reported that they acquire technical knowledge and skills from 
the trainings, learning and development program, whereas $54 \%$ were found against the opinion. This result is clear indication of employees do not acquire technical knowledge.

- Regarding training need assessment, majority (53\%) reported that they don't take part in training need assessment prior to designed and carry out the trainings whereas only $47 \%$ of them reported that they are provided this opportunity. So, it means that NRB lacks adequate practice of involving employees in decision making and assessment process in relation to training development and implementation.

- Majority of the respondents (55\%) were against the view of NRB's capacity on providing good career opportunity and higher education facility, whereas only $45 \%$ of them were in favor of this statement. This result shows that overall employees performance and development practice seems to be below standard.

- In response to the statement: Human Resource development helps in corporate governance, coordination and motivation $69 \%$ of the respondents agreed and only $31 \%$ expressed their disagreement. This indicates that if organization takes an initiative in an effective human resource management would help in enhance good governance, capacity, motivation and coordination of organization.

- Regarding the query of Training and Development, majority of the respondent (68\%) expressed their agreement on the statement: Training and development of the employees helps for change management, whereas $32 \%$ of the respondents were against the statement. It is obvious that the majority of the respondents regards training and development as an important tool for change management.

- To find out the view of employees regarding employee development they were asked cast their view on the statement: Employees' development helps to enhance the sense of confidence to which majority of the respondent $(62 \%)$ agreed and $38 \%$ expressed their disagreement. It indicated that most of the employees in NRB perceive employee training and development programmes creates sense of confidence to them.

- Majority of the respondents (60\%) agreed on the opinion that 'training helps the organization to change the challenges into opportunities and weaknesses into strengths.' While rest $40 \%$ were against this statement. It indicates that to strengthen the organizational capacity employee should be trained and developed.

- Regarding the benefits of training and development program majority of the respondents (62\%) agreed on the statement: training and development helps to improve productivity, market share, reputation, image, prestige and efficient use of resources. On the contrary only $38 \%$ of the respondents showed their disagreement. This clearly shows that if the organization provides training and development programmes to its employee it helps to improve productivity, extend market share, reputation in the market or customer. In addition, it also enhances the prestige of the organization as well as helps the efficient use of the resources.

- Most of the respondent (54\%) opined that employees' development helps to promote corporate governance, coordination and motivation while $46 \%$ of the respondents were against this opinion. On the contrary, $56 \%$ of the respondents were found against the statement: training and development helps the change management and grievance management system and only $43 \%$ agreed to it. On the statement: training helps the organization to transform the changes into opportunity and weakness into strength, majority of the respondents $(73 \%)$ casted their agreement and only 27 $\%$ were against this opinion.

- Majority of the respondents (52\%) found that employee's development helps research and development activities, employees' creativity, internal control system, monitoring and supervision. Human resource development has improved decision making capabilities and cultured thinking of management. Well skilled employees have adjusted with job related problems.

- Trained employees helped subordinate to improve their performance that leads to employee participation and cooperation. Respondents agreed that employees' development equips manager to pro-act as well as to respond to changing environmental forces. For the purpose of effective operation of financial and accounting system, each and every organization should follow the budgeting and financial management systems. Similarly skilled man power have mobilized effectively and efficiently the budgeting and financial management system in NRB.

- Sometimes it was also found that there is a problem of goal congruence among the employees due to the lack of controlling. Regarding the question of quality of work life and commitment they agreed that employees' development leads to commitment, readiness to change, societal well-being, cost effectiveness and implementation of monetary policies.

\section{CONCLUSION}

The main aim of the study was assess to find out the employee development and organizational performance of NRB. Study was quite successful to meet the designed objectives of this research. It was designed to find out the employee development practice, establish a link between employee development and organizational performance of the bank. It is obvious that from the above analysis of data employees training and development program has positive relationship with performance. Present study can be a valuable piece of research works in Human Resource Development particularly in training, development, performance evaluation system and organizational climate aspects in Nepal Rastra Bank. It may be helpful for academicians, bank management and any others who are 
directly or indirectly involved in business, government and non-government sectors.

\section{REFERENCES}

[1] Armstrong, M. (2014). Armstrong's Handbook of Human Resource Management Practice. 11th edition. United Kingdom: Kogan Page Limited.

[2] Armstrong, M. (2014). Strategic Human Resource Management. London: Kogan Page Limited.

[3] Brown, F.W. and Dodd, N.G. (1998). 'Utilizing organizational cultural gap analysis to determine human resource management needs'. Leadership and organization development journal, 19/7, pp. 374-385.

[4] CIMA (2013). Organisation Management and Information System. Kaplan Publishing.

[5] Doyle, M. (2000). 'Management development in an era of radical change: evolving a relational perspective'. Journal of Management Development, Vol. 19 No. 2.

[6] Kitaura, M. (1996). 'The current state of human resource development administration in Japan and the debate on its future'. Journal of management development, Vol.15, No.8, pp 17-29.

[7] NRB (2015). 'Strategic Plan 2010-2015'. NRB publication.

[8] Ogbu, J. (1987). 'Variability in minority school performance: A problem in search of an explanation'. Anthropology and Education Quarterly, 18(4), 312-334.
[9] Pervez, N. G. and Kjell, G. (2005). Research methods in business studies: a practical guide. 3rd edition. Prentice Hall.

[10] Pokhrel, S. P. (1982). Roles of Bankers' Training Centre in the Manpower Development of Nepal. Central Department of Management, TU.

[11] Ranjit, K. (2011). Research Methodology. 3rd editions. UK: Sage Publication Limited.

[12] Rao, T.V. (1998). The HRD Missionary. New Delhi: Oxford and IBH publishing co. pvt. Ltd.

[13] Redman, T. and Wilkinson A. (2006). Contemporary Human Resource Management -Text and Cases. 2nd edition. UK: Prentice Hall, Financial Times.

[14] Smith, A. and Smith, E. (2007). The Role of the Training in the Development of Human Resource Development in Australian Organisations. Human Resource Development International. Vol. 10, No. 3, pp. 263-279.

[15] Som, A. (2008). Innovation Human Resource Management and Corporate Performance in the context of economic liberalization in India. The International Journal of Human Resource. Vol IX.

[16] Swanson, A. R. and Elwood, F. Hilton III (2009). Foundation of Human Resource Development. 2nd edition. USA: Berrett-Koehler Publishers Inc.

[17] Wilson, P. John (1999). Human Resource Development. United Kingdom: Kogan Page Limited. 